\title{
DIVERSI TINDAK PIDANA NARKOTIKA DALAM SISTEM PERADILAN PIDANA ANAK
}

\author{
Oleh: \\ I Made Wiharsa ${ }^{1}$
}

\begin{abstract}
Diversion of narcotic crime in the criminal justice system for the children. Children in conflict with the law, especially in narcotic cases not specifically regulated in Law Number 35 of 2009 on the Narcotics. During this time the children in conflict with the law that is drafted in the Law Number 11 of 2012 on the Criminal Justice System for The Children. Criminal punishment against with a certain person started because that person has committed a crime. Children in the case of a criminal act of narcotics criminal sanctions will have a negative impact on a child's future. Referring to the criminal justice system for the children are known to attempt a diversion to divert the child's completion of the criminal case of the trial into a non-judicial process. This research with the normative methods research type, which aims to determine the impact of the imposition of criminal sanctions and diversion efforts for children in narcotic crime.
\end{abstract}

Keywords: Diversion, Children, Narcotic

\begin{abstract}
Abstrak
Diversi tindak pidana narkotika dalam sistem peradilan pidana anak. Anak yang berkonflik dengan hukum khususnya dalam tindak pidana narkotika belum diatur secara khusus dalam Undang-Undang Nomor 35 Tahun 2009 Tentang Narkotika. Selama ini terhadap anak yang berkonflik dengan hukum mengacu pada Undang-Undang Nomor. 11 Tahun 2012 Tentang Sistem Peradilan Pidana Anak. Penjatuhan pidana terhadap seseorang bermula karena seseorang tersebut telah melakukan suatu tindak pidana. Anak dalam hal melakukan tindak pidana narkotika yang dijatuhi sanksi pidana akan berdampak buruk pada masa depan anak. Mengacu pada sistem peradilan pidana anak yang dikenal upaya diversi untuk mengalihkan penyelesaian perkara tindak pidana anak dari proses peradilan ke proses non peradilan. Penelitian ini menggunakan metoda penelitian hukum normatif, yang bertujuan untuk dapat mengetahui dampak penjatuhan sanksi pidana dan upaya diversi bagi anak dalam tindak pidana narkotika.
\end{abstract}

\section{Kata Kunci: Diversi, Anak, Narkotika.}

\section{PENDAHULUAN}

Anak merupakan amanah dan karunia Tuhan Yang Maha Esa yang memiliki harkat dan martabat sebagai manusia seutuhnya. Undang-Undang Dasar Negara Republik Indonesia Tahun 1945 mengamanatkan bahwa setiap anak berhak atas kelangsungan

1 Program Studi Magister Ilmu Hukum Fakultas Hukum Universitas Udayana Denpasar, Bali. Email : outhounkz@yahoo.com 
hidup, tumbuh dan berkembang serta berhakatas perlindungandarikekerasan dan diskriminasi. Anak sebagai tunas, potensi, dan generasi muda penerus cita-cita perjuangan bangsa memiliki peran strategis, ciri, dan sifat khusus sehingga wajib dilindungi dari segala bentuk perlakuan tidak manusiawiyang mengakibatkan terjadinya pelanggaran hak asasi manusia. Tiap-tiap anak wajib mendapatkan pembinaan sejak dini bahkan sejak dalam kandungan pun anak mendapatkan perlindungan, anak perlu mendapat hak yang seluasluasnya agar dapat tumbuh serta berkembang secara maksimal, baik secara fisik, mental bahkan sosial. Masa kanak-kanak adalah masa dalam periode penaburan benih, pendirian tiang pancang, serta pembuatan pondasi, yang dapat disebut juga sebagai periode pembentukan watak, kepribadian dan karakter diri seorang anak, agar anak-anak tersebut kelak memiliki kekuatan dan kemampuan serta berdiri tegar dalam menjalani kehidupan di masa mendatang ${ }^{2}$.

Jaman yang serba modern ini, kenakalan anak bukan lagi dianggap sebagai kenakalan biasa. Anakanak seolah-olah menjadikan suatu kenakalan tersebut sebagai kebiasaan sehari-hari di dalam pergaulan mereka. Kenakalan tersebut terkadang merupakan suatu perbuatan yang tergolong tindak pidana, seperti:

2 Maidin Gultom, 2008, Perlindungan Hukum Terhadap Anak dalam Sistem Peradilan Pidana Anak di Indonesia, Refika Aditama, Bandung, hlm. 1. mencuri, memperkosa, bahkan menggunakan obat-obatan berbahaya atau sering disebut dengan narkotika. Narkotika salah satunya, yaitu obatobatan terlarang yang memiliki zat aktif dan pengaruhnya jika digunakan yaitu berupa pembiasan, hilangnya rasa sakit rangsangan, semangat dan halusinasi. Dengan timbulnya efek halusinasi inilah yang menyebabkan kelompok masyarakat terutama di kalangan anak-anak atau remaja ingin menggunakan narkotika sehingga timbul penyalahgunaan narkotika. Narkotika jika digunakan akan menimbulkan efek ketergantungan atau adiksi obat yaitu suatu kelainan obat yang bersifat kronik/periodik sehingga penderita kehilangan kontrol terhadap dirinya dan menimbulkan kerugian terhadap dirinya dan masyarakat ${ }^{3}$.

Pemerintah, orang tua maupun masyarakat harus lebih bersikap untuk memberikanperhatianyanglebihserius. Anak memiliki sifat yang masih sangat labil dalam hal emosi, apabila terdapat penanganan kasus kejahatan dengan pelaku anak, maka anak tersebut perlu mendapat perhatian khusus. Seorang tidak dapat dihukum oleh karena melakukan suatu kesalahan, apabila sebelum ia melakukan kesalahan itu, belum terdapat adanya ketentuan pasal dari suatu Undang-Undang yang menyatakan bahwa kesalahan yang diperbuatnya itu diancam dengan

3 Julianan Lisa FR dan Nengah Sutrisna W, 2013, Narkoba, Psikotropika, dan Gangguan Jiwa Tinjauan Kesehatan dan Hukum, Nuha Medika, Yogyakarta, hlm. 2 
hukuman. Hal tersebut merupakan cerminan dari asas Nullum Delictum, Nulla Poena Sine Praevia lege Poenali, asas tersebut terdapat dalam ketentuan Pasal 1 ayat (1) KUHP.

Amerika Serikat membuat suatu upaya dengan membentuk UndangUndang Sistem Peradilan Pidana Anak (juvenile court) yang pertama di Minos Amerika Serikat tahun 1889. UndangUndang tersebut didasarkan pada azas parens patrie, yang berarti "penguasa harus bertindak apabila anak-anak yang membutuhkan pertolongan", sedangkan anak dan pemuda yang melakukan kejahatan sebaiknya tidak diberi pidana melainkan harus dilindungi dan diberi bantuan ${ }^{4}$.

Upaya tersebut tidak hanya dilakukan oleh Amerika Serikat, untuk mewujudkan hal serupa di Indonesia juga telah dibentuk UndangUndang yang mengatur mengenai Sistem Peradilan Pidana Anak yaitu Undang- Undang Nomor 11 Tahun 2012 pengganti Undang-Undang No. 3 Tahun 1997 tentang Pengadilan Anak. Semua ketentuan dalam Undang-Undang Nomor 11 Tahun 2012 tentang Sistem Peradilan Pidana Anak (selanjutnya disebut UU SPPA) yang sangat erat hubungannya dengan perlakuan khusus terhadap pelaku tindak pidana anak. Ketika berbicara masalah perlindungan hukum bagi anak tidak dapat dilepaskan dari

4 Wagiati Soetodjo, 2006, Hukum Pidana Anak, PT.Refika Aditama, Bandung, hlm. 1. tujuan dasar peradilan anak yaitu untuk mewujudkan kesejahteraan anak dengan mendahulukan atau mengutamakan kepentingan anak.

Konvensi Perserikatan BangsaBangsa Tahun 1989 Tentang Hak-Hak Anak menyatakan bahwa tindakan hukum yang dilakukan terhadap mereka yang berusia di bawah 18 tahun harus mempertimbangkan kepentingan terbaik anak. Ketentuan Pasal 1 angka 3 UU SPPA, anak yang berkonflik dengan hukum yang selanjutnya disebut Anak adalah anak yang telah berumur 12 (dua belas) tahun, tetapi belum berumur 18 (delapan belas) tahun yang diduga melakukan tindak pidana. Anak bukanlah sebagai miniatur orang dewasa tentunya yang memerlukan penanganan khusus terhadap anak yang bermasalah di hadapan hukum. Anak yang berhadapan dengan perkara narkotika ketika dipertanggungjawabkan dalam sebuah sistem pemidanaan yang ada dalam Undang-Undang Nomor 35 Tahun 2009 Tentang Narkotika (selanjutnya disebut Undang-Undang Narkotika), hakim dalam menangani perkara tersebut wajib bersungguhsungguh dan memegang teguh filosofi pokok yaitu untuk kepentingan terbaik anak dalam mencapai suatu keadilan ${ }^{5}$.

5 Susi Pangaribuan, 2012, Tinjauan Terhadap Sistem Pemidanaan Minimal Bagi Anak Dalam Perkara Narkotika Dengan Kerangka Kepentingan Terbaik Anak, Varia Peradilan, No. 325 , hlm.56 
Penggunaan sanksi pidana bagi anak secara teoritis dan secara yuridis tetap dimungkinkan, mengingat bahwa penggunaan sanksi pidana bagi tersebut tidak dapat disamakan dengan penggunaan sanksi pidana bagi orang dewasa.Penggunaan sanksipidanabagi anak ditentukan dengan persyaratanpersyaratan yang sangat ketat, artinya penjatuhannya juga harus sangat selektif dan pelaksanaannya harus disesuaikan dengan kondisi kejiwaan si anak. Oleh karena itu sangat ironis dan sangat tidak dapat dibenarkan, apabila terdapat anak yang menjalani pidana bersama-sama dengan orang dewasa.

Secara umum di dalam KUHP terdapat tiga rumusan pasal yang mengatur tentang sanksi pidana terhadap anak. Pertama, pada ketentuan Pasal 45 KUHP yang mengatur tentang batas maksimum seorang anak dapat dipertanggungjawabkan atas tindak pidana yang dilakukannya. Kedua, ketentuan Pasal 46 yang mengatur tentang aturan administrasi berkaitan dengan apa yang harus dikerjakan hakim setelah ia memberi perintah, bahwa yang bersalah diserahkan kepada pemerintah. Ketiga yaitu ketentuan Pasal 47 yang mengatur tentang pengurangan pidana dalam hal hakim akan menjatuhkan pidana kepada pelaku anak. Namun setelah diundangkannya Undang-Undang No.3 Tahun 1997 tentang Pengadilan Anak yang dicabut dan diganti dengan
Undang-Undang No. 11 Tahun 2012 tentang Sistem Peradilan Pidana Anak, ketentuan Pasal 45, 46 dan 47 KUHP tersebut dinyatakan tidak berlaku lagi.

Anak yang berkonflik dengan hukum atau yang diduga melakukan tindak pidana khususnya tindak pidana narkotika, jika dicermati terdapat beberapa ketentuan pasal dalam Undang-Undang Narkotika yang khusus diberlakukan bagi anak, yaitu pasal pengecualian terhadap mereka yang belum cukup umur. Namun demikian, Undang-Undang Narkotika tidak secara khusus mengatur tentang stelsel sanksi pidana bagi anak. Oleh karena itu, berlakunya stelsel sanksi pidana dalam UndangUndang Narkotika terhadap anak, juga harus diberlakukannya juga UU SPPA sebagai ketentuan khusus yang diterapkan terhadap anak, hal ini sebagai konsekuensi adanya asas lex specialist derogat legi generalis ${ }^{6}$.

UUSPPA dalam hal ini menganut konsep keadilan restoratif yang diwujudkan melalui upaya diversi. Keadilan restoratif atau restoratif justice adalah model penyelesaian perkara pidana yang mengedepankan pemulihan kembali terhadap korban, pelaku, dan masyarakat. Tujuan keadilan restoratif adalah adanya partisipasi korban dan pelaku, partisipasi warga sebagai fasilitator

6 Koesno Adi, 2014, Diversi Tindak Pidana Narkotika Anak, Setara Press, Malang, hlm. 23 
dalam penyelesaian kasus, sehingga ada jaminan anak atau pelaku tidak lagi mengganggu harmoni yang sudah tercipta di masyarakat ${ }^{7}$.

Pada dasarnya seorang anak belum dapat menentukan perbuatan apa yang dianggap baik atau buruk. Perbuatan anak yang tergolong sebagai tindak pidana pada umumnya adalah perbuatan yang ditiru sebagaimana perbuatan yang dilakukan orang dewasa. Sistem peradilan pidana kita saat ini berpotensi terhadap tumbuh dan kembang anak khususnya yang berstatus narapidana untuk kedepannya. Anak yang dipenjara tidak akan berhasil menjadi jera sepenuhnya melainkan dapat berpotensi menjadi anak yang lebih profesional dalam melakukan tindak pidana. Anak yang terlibat tindak pidana narkotika, contohnya seperti anak yang semula hanya mengetahui cara menghisap ganja, setelah masuk penjara, anak tersebut mengetahui cara bertransaksi dari dalam penjara. Perspektif sudut pandang psikologis, berbagai sikap dan tindakan sewenangwenang terhadap anak, serta semakin kompleksnya masalah yang dihadapi anak-anak zaman sekarang, ditambah lagi faktor-faktor penunjang untuk terjadinya proses belajar secara tidak

7 I Made Wahyu Chandra Satriana, 2013, Kebijakan Formulasi Keadilan Restoratif Dalam Sistem Peradilan Pidana Anak, Jurnal Magister Hukum Udayana,No. 3, Vol. 3, Edisi Juli 2013, http://ojs.unud. ac.id/index.php/jmhu/article/view/7309. diakses tanggal 29 Desember 2016. langsung, seperti tayangan-tayangan kekerasan di televisi, sampai dengan berita kekerasan serius yang muncul akhir-akhir ini. Sementara pada diri seorang anak, proses imitasilah atau meniru paling dominan memberikan pengaruh terhadap dirinya ${ }^{8}$.

Berangkat dari latar belakang di atas, dalam penelitian ini dapat ditentukan rumusan masalah sebagai berikut:

1. Apakahdampakpemidanaanbagi terpidana anak yang melakukan penyalahgunaan narkotika?

2. Bagaimanakah upaya diversi terhadap anak yang menyalahgunakan narkotika?

Penelitian ini merupakan karya ilmiah asli yang belum pernah diteliti sebelumnya. Adapun karya ilmiah yang terkait dengan karya ilmiah Penulis tentang Diversi Tindak Pidana Narkotika Dalam Sistem Peradilan Anak yaitu karya ilmiah dari Made Ayu Citra Maya Sari tahun 2013 dengan judul Diversi Dalam Sistem Peradilan Anak yang rumusan masalahnya adalah; 1. Bagaimana konsepsi ide diversi oleh legislator dalam memberikan perlindungan hukum terhadap anak yang berkonflik dengan hukum?; 2. Apakah ide diversi telah diimplementasikan

8 Made Ayu Citra Maya Sari, 2013, Diversi Dalam Sistem Peradilan Pidana Anak Di Indonesia, Jurnal Magister Hukum Udayana, No. 1, Vol. 2, Edisi Pebruari 2013, http://ojs.unud.ac.id/index.php/ jmhu/article/view/4439, diakses tanggal 29 Desember 2016. 
dalam Undang-Undang Nomor 11 Tahun 2012 tentang Sistem Peradilan Pidana Anak tersebut?. Karya ilmiah lainnya yang terkait yaitu I Made Wahyu Chandra Satriana tahun 2013 dengan judul Kebijakan Formulasi Keadilan Restoratif Dalam Sistem Peradilan Pidana Anak yang rumusan masalahnya adalah; 1. Apakah ide dasar keadilan restoratif dalam sistem peradilan pidana anak?; 2 . Bagaimanakah kebijakan formulasi keadilan restoratif dalam UndangUndang No. 11 tahun 2012 Tentang Sistem Peradilan Pidana Anak?. Jelas nampak perbedaan dari karya ilmiah tersebut dengan karya ilmiah yang dibuat oleh Penulis. Adapun keunggulan karya ilmiah ini dari karya ilmiah lainnya yaitu membahas lebih dalam tentang dampak negatif yang timbul jika anak dijatuhkan pidana penjara dan membahas lebih dalam upaya diversi terhadap anak yang melanggar ketentuan Pasal 127 Undang-Undang Narkotika.

Tujuan dari penelitian ini adalah untuk memberikan gambaran yang jelas tentang dampak dari penjatuhan sanksi pidana dan upaya diversi bagi terpidana anak yang menyalahgunakan narkotika dalam Undang-Undang Narkotika dengan berlakunya UU SPPA.

\section{METODE PENELITIAN}

Penelitian hukum merupakan segala aktifitas seseorang untuk menjawab permasalahan hukum yang bersifat akademik dan praktis, baik yang bersifat asas-asas hukum, norma-norma hukum yang hidup dan berkembang dalam masyarakat yang berkenaan dengan kenyataan hukum dan masyarakat ${ }^{9}$. Penulisan karya ilmiah ini menggunakan jenis penelitian hukum normatif. Menurut pandangan Abdulkadir Muhammad dalam bukunya yang berjudul "Hukum dan Penelitian Hukum", menyatakan bahwa ${ }^{10}$ :

"Penelitian hukum normatif adalah penelitian hukumyang mengkaji hukum tertulis dari berbagai aspek yaitu aspek teori, sejarah, filosofi, perbandingan, struktur dan komposisi, lingkup dan materi konsistensi, penjelasan umum dan pasal demi pasal, formalitas dan kekuatan mengikat suatu Undang-Undang, serta bahasa hukum yang dipergunakan".

Penelitian hukum normatif dilakukan dengan cara meneliti bahan hukum yang diperoleh dari bahan hukum primer, bahan hukum sekunder dan bahan hukum tersier, serta dalam penelitian hukum ini mempergunakan pendekatan dalam memecahkan masalah, yaitu dengan menggunakan pendekatan perundang-undangan (the statute approach) yang berhubungan dengan masalah yang dibahas ${ }^{11}$.

9 Zainuddin Ali, 2009, Metode Penelitian Hukum, Sinar Grafika, Jakarta, hlm.19

10 Abdulkadir Muhammad, 2004, Hukum dan Penelitian Hukum, PT Citra Aditya Bakti, Bandung, hlm. 101

11 Peter Mahmud Marzuki, 2011, Penelitian Hukum, Kencana Prenada Media Group, Jakarta, hlm. 93 
III. HASIL DAN PEMBAHASAN 3.1 Dampak Pemidanaan Bagi Anak Yang Melakukan Penyalahgunaan Narkotika

Anak yang terlibat kejahatan narkotika atau anak yang menyalahgunakan narkotika tentu tidak secara tiba-tiba dapat melakukan hal tersebut, melainkan melalui proses sindikat peredaran gelap narkotika, dimana kejahatan narkotika memang menjanjikan keuntungan yang besar serta menyebabkan ketergantungan terhadap pemakainya. Pihak kepolisian tentunya melakukan tindakan atau langkah-langkah untuk melakukan upaya penanggulangan kejahatan terhadap penyalahgunaan narkotika. Pihak kepolisian secara garis besar dengan menindak secara tegas atau menerapkan ketentuan sanksi pidana yang berorientasi pada upaya untuk memberantas/ menumpas sesudah kejahatan terjadi (repressive) dan melalui jalur antisipatif dengan berupaya mencegah (preventive) sehingga tidak perlu diterapkan ketentuan sanksi pidana, yang berorientasi pada upaya untuk mencegah/menangkal sebelum kejahatan terjadi ${ }^{12}$.

Mengingat teori pemidanaan yaitu penjatuhan pidana semata-mata karenaseseorang telahmelakukan suatu kejahatan atau tindak pidana. Menurut teori ini, hukuman itu dijatuhkan sebagai pembalasan terhadap para pelaku karena telah melakukan kejahatan yang mengakibatkan kesengsaraan terhadap orang lain atau anggota masyarakat ${ }^{13}$.

Menurut pendapat dari Karl O. Christinsen mengidentifikasikan 5 (lima) ciri pokok dari teori pembalasan atau retributif ini, yakni:

1. The purpose of punishment is just retribution (tujuan pidana hanya sebagai pembalasan);

2. Justretributionistheultimateaim, and not in itself a means to any other aim, as for instance social welfare which fom this point of view is without any significance whatsoever (pembalasan ialah tujuan utama dan di dalamnya tidak mengandung saranasarana untuk tujuan lain seperti kesejahteraan masyarakat);

3. Moral guilt is the only qualification for punishment (kesalahan moral sebagai satu-satunya syarat untuk pemidanaan);

4. The penalty shall be proportional to the moral guilt of the offender (pidana harus disesuaikan dengan kesalahan si pelaku);

5. Punishment point into the past, it is pure reproach, and it purpose is not to improve, correct, educate or resocialize the offender (pidana melihat ke belakang, ia sebagai pencelaan yang murni dan bertujuan tidak untuk memperbaiki, mendidik, dan meresosialisasi pelaku) ${ }^{14}$.

13 Leden Marpaung, 2012, Asas-Teori-Praktik Hukum Pidana, Sinar Grafika, Jakarta, hlm. 4

14 Karl OChristiansen, 1974, Some Consideration on the Possibility of a Rational Criminal Policy, Resource Material Series No.7, UNAFEI, Tokyo, page 69 
Dasarpembenaran adanyapidana adalah terletak pada tujuannya. Pidana dijatuhkan bukan "quia peccatum est" (karena orang berbuat kejahatan) melainkan "ne peccetur" (supaya orang jangan melakukan kejahatan) ${ }^{15}$. Tujuan pemidanaan pada dasarnya terdapat tiga pokok pemikiran tentang tujuan yang ingin dicapai dengan suatu pemidanaan, yaitu:

1. Untuk memperbaiki pribadi dari penjahat itu sendiri;

2. Untuk membuat orang menjadi jera dalam melakukan kejahatankejahatan;

3. Untuk membuat penjahat tertentu menjadi tidak mampu melakukan kejahatan lain, yakni penjahat yang dengan cara-cara yang lain sudah tidak dapat diperbaiki lagi ${ }^{16}$.

Menurut Van Hamel tujuan pemidanaan adalah sebagai berikut:

1. Pemidanaan harus memuat suatu anasir yang menakutkan supaya si pelaku tidak melakukan niat buruk;

2. Pemidanaan harus memuat suatu anasir yang memperbaiki bagi terpidana yang nantinya memerlukan suatu reclessering;

3. Pemidanaan harus memuat suatu anasir membinasakan bagi penjahat yang sama sekali tidak dapat diperbaiki lagi;

15 Ibid

16 P.A.F.Lamintang dan Theo Lamintang, 2012, Hukum Penitensier, Cetakan Kedua, Sinar Grafika, Jakarta, hlm. 11
4. Tujuan satu-satunya dari pemidanaan adalah mempertahankan tata tertib hukum ${ }^{17}$.

Penjatuhan pidana penjara bagi anak tentunya akan membawa dampak negatif yang berkepanjangan, yang justru bersifat kontra produktif jika dilihat dari tujuan pemidanaan itu sendiri. Tujuan pemidanaan khususnya bagi anak, dalam kenyataannya tidak dapat dipenuhi dengan penjatuhan pidana penjara kepada anak. Pemidanaan bagi anak seringkali menempatkan anak pada situasi yang akan merugikan anak tersebut di kemudian hari. Perlakuan buruk yang dihadapi juga terkadang masih terjadi ketika anak berada dalam tahanan ataupun dalam Lembaga Pemasyarakatan (LAPAS), seperti pemalakan bahkan diancam untuk ikut serta dalam transaksi gelap narkotika oleh tahanan atau narapidana dewasa. Hal tersebut dimungkinkan terjadi walaupun sel anak dan sel dewasa ditempatkan secara terpisah, karena minimnya fasilitas antara narapidana anak dan narapidana dewasa masih dapat berinteraksi ${ }^{18}$. Hal tersebut berdampak secara langsung terhadap anak, karena anak memiliki kebiasaan untuk meniru, dan selama di lingkungan penjara dikhawatirkan anak tersebut akan ikut terlibat serta banyak belajar tentang kejahatan khususnya narkotika. Bahwasanya ada beberapa faktor penyebab keterlibatan

17 Ibid., hlm. 18

18 Koesno Adi, Op.Cit., hlm. 103 
narapidana dalam peredaran gelap narkotika, baik faktor internal maupun eksternal. Faktor internal berkaitan dengan masalah sarana dan prasarana serta pengawasan dan kontrol petugas di dalam Lapas itu sendiri, sedangkan faktor eksternal yang dihadapi berkaitan dengan kecenderungan yang sangat tinggi dijatuhkannya sanksi penjara/pengurungan atas pelanggaran hukum sehingga akibat dominasi penjatuhan pidana penjara tersebut ${ }^{19}$.

Secara umum, penerapan sanksi pidana terhadap anak justru akan menimbulkan dampak negatif yang lebih luas dan kompleks dibandingkan dengan penerapan sanksi pidana terhadap orang dewasa. Made Sadhi Astuti berpendapat bahwa penerapan sanksi pidana anak akan menimbulkan kerugian yaitu:

1. Anak menjadi lebih ahli tentang kejahatan;

2. Anak diberi cap jahat oleh masyarakat yang disebut stigma;

3. Masyarakat menolak kehadiran mantan narapidana anak;

4. Masa depan anak menjadi suram $^{20}$.

Muladi berpendapat bahwa

19 I Gede Artha dan I Wayan Wiryawan, Pengendalian Peredaran Gelap Narkotika Oleh Narapidana Dari Dalam Lembaga Pemasyarakatan (LAPAS), Jurnal Magister Hukum Udayana, No. 3, Vol. 4, Edisi September 2015, http://ojs. unud.ac.id/index.php/jmhu/article/view/ 18065,diakses tanggal 29 Desember 2016

20 Koesno Adi, Op.Cit., hlm. 141 dampak pidana penjara tidak hanya dirasakan oleh terpidana yang dalam hal ini adalah anak, melainkan juga pada keluarga maupun orang-orang yang hidupnya tergantung pada terpidana $^{21}$. Realitasnya banyak anak yang terpaksa harus membantu bekerja karena justru harus menjadi tulang punggung ekonomi keluarganya. Dampak lainnya bagi masyarakat, kerugian nampak dari sering timbulnya residivisme sebagai akibat penjatuhan sanksi pidana penjara.

Penjatuhan pidana penjara dalam perkara tindak pidana narkotika oleh hakim khususnya kepada anak kadang bersifat represif oleh karena belum adanya ketentuan pasal yang mengatur tentang anak yang menyalahgunakan narkotika. Berdasarkan UndangUndang Narkotika, bahwa tindak pidana narkotika diancam dengan sanksi pidana yang tinggi dan berat dengan dimungkinkannya terdakwa divonis maksimal yakni pidana mati selain pidana penjara dan pidana denda. Mengingat tindak pidana narkotika termasuk dalam jenis tindak pidana khusus maka ancaman pidana terhadapnya dapat dijatuhkan secara kumulatif dengan menjatuhkan 2 jenis pidana pokok sekaligus, misalnya pidana penjara dan pidana denda atau pidana mati dan pidana denda. Pidana penjara seharusnya dijatuhkan kepada anak justru dilakukan ketika tidak ada alternatif lain. Adapun secara teoritis kecenderungan hakim yang selalu

$21 \quad$ Koesno Adi, Op.Cit., hlm. 104 
menjatuhkan pidana penjara kepada anak dapat dipersoalkan karena beberapa hal berikut:

1. Pidana pada dasarnya merupakan sebuah alat untuk mencapai tujuan pemidanaan. Apabila fungsi dari alat tersebut tidak dapatmemenuhitujuanyangtelah ditentukan, maka tidak ada alasan untuk tetap menggunakan alat tersebut. Tidak adanya jaminan jika anak yang dijatuhi pidana penjara maka dengan sendirinya ia akan kembali menjadi anggota masyarakat yang baik dan taat hukum. Justru seringkali diketahui bahwa pidana penjara membawa dampak negatif yang sangat merugikan bagi terpidana khususnya terpidana anak.

2. Penggunaan hukum pidana sebagai sarana penanggulangan penyalahgunaan narkotika, hanya dapat dibenarkan manakala dampak negatif digunakannya pidana penjara sebagai sarana penanggulangan penyalahgunaan narkotika dilakukan oleh anak mengandung kelemahan mendasar. Hal ini disebabkanolehkarenaefektifitas penggunaan pidana penjara sebagai sarana penanggulangan penyalahgunaan narkotika belum diketahui efektifitasnya, sementara dampak negatifnya relatif dapat dipastikan ${ }^{22}$.

22 Koesno Adi, Op.Cit., hlm. 105

\subsection{Upaya Diversi Terhadap Anak Yang Menyalahgunakan Narkotika}

Anak yang melakukan tindak pidana pada dasarnya adalah anak yang bermasalah dan dikategorikan dalam istilah kenakalan anak. Istilah kenakalan anak mengacu pada ketentuan Undang-Undang Nomor 3 Tahun 1997 Tentang Pengadilan Anak, kemudian setelah berlakunya UndangUndang No. 11 Tahun 2012 Tentang Sistem Peradilan Pidana Anak maka istilah kenakalan anak tersebut berubah menjadi istilah anak yang berkonflik dengan hukum ${ }^{23}$.

UU SPPA tidak semata-mata bertujuan untuk menjatuhkan sanksi pidana bagi anak pelaku tindak pidana, tetapi lebih difokuskan pada dasar pemikiran bahwa penjatuhan sanksi tersebut sebagai sarana mendukung mewujudkan kesejahteraan anak pelaku tindak pidana ${ }^{24}$. Dalam hal mewujudkan kesejahteraan anak sebagai pelaku tindak pidana sedapat mungkin anak tersebut agar terhindar dari keterlibatan anak dalam proses sistem peradilan pidana anak. Hal tersebut akan berdampak negatif bagi psikologis anak itu sendiri, maka dari itu aparat penegak hukum diberikan kewenangan untuk mengalihkan penyelesaian perkara tindak pidana anak dari proses peradilan ke proses

23 M. Nasir Jamil,2013, Anak Bukan Untuk Dihukum, Sinar Grafika, Jakarta, hlm. 32.

24 Setya Wahyudi, 2011, Implementasi Ide Deversi Dalam Pembaharuan Sistem Peradilan Anak Di Indonesia, Cet. Ke 1 , Genta Publishing, Yogyakarta, hlm. 1. 
non peradilan yang disebut dengan diversi. Dengan demikian, adalah tidak pada tempatnya apabila proses peradilan anak hanya dilakukan atas alasan untuk mencari legitimasi yuridis-sosiologis terhadap pidana yang dijatuhkan hakim berupa pidana perampasan kemerdekaan ${ }^{25}$. Penegasan terhadap hal ini secara eksplisit tertuang dalam Resolusi PBB 45/113 yang mulai berlaku pada tanggal 14 Desember 1990, perlunya ditegakkan dan dilindungi hakhak dan keselamatan anak di dalam penyelenggaraan peradilan anak, guna terwujudnya kesejahteraan fisik dan mental $^{26}$.

UU SPPA dalam ketentuan Pasal 1 angka 7 menyatakan bahwa diversi adalah pengalihan penyelesaian perkara Anak dari proses peradilan pidana ke proses di luar peradilan pidana. Adapun tujuan diversi yang dinyatakan pada ketentuan Pasal 6 UU SPPA, yaitu:

Diversi bertujuan:

1. mencapai perdamaian antara korban dan Anak;

2. menyelesaikan perkara Anak di luar proses peradilan;

3. menghindarkan Anak dari perampasan kemerdekaan;

4. mendorong masyarakat untuk berpartisipasi; dan

5. menanamkan rasa tanggung jawab kepada Anak.

25 Koesno Adi, Op.Cit., hlm. 122

26 Loc.Cit.
Menurut Setya Wahyudi, adapun manfaat pelaksanaan program diversi bagi pelaku tindak pidana anak dapat dikemukakan sebagai berikut:

a. Membantu anak-anak belajar dari kesalahannya melalui intervensi secepat mungkin;

b. Memperbaiki luka-luka akibat kejadian tersebut, kepada keluarga, korban dan masyarakat;

c. Kerjasama dengan pihak orang tua, pengasuh, dan diberi nasehat dalam hidup sehari-hari;

d. Melengkapi dan membangkitkan rasa tanggung jawab anakanak untuk membuat suatu keputusan;

e. Berusaha untuk mengumpulkan dana untuk memberikan restitusi kepada korban;

f. Memberikan tanggung jawab anak atas perbuatannya, dan memberikan pelajaran tentang kesempatan untuk mengamati akibat-akibat dan efek kasus tersebut;

g. Memberikan pilihan kepada pelaku untuk berkesempatan menjaga agar tetap bersih atas cacatan kejahatan;

h. Mengurangi beban pada peradilan dan lembaga penjara;

i. Pengendalian kejahatan anak/ remaja ${ }^{27}$.

Ide diversi ini pada dasarnya untuk menghindari efek negatif pemeriksaan konvensional peradilan

27 Setya Wahyudi , Op.Cit., hlm. 60 
pidana anak terhadap anak, baik efek negatif proses peradilan maupun efek negatif stigma atau cap jahat proses peradilan, maka pemeriksaan secara konvensional dialihkan, dan kepada anak tersebut dikenakan programprogram diversi. Adapun syarat-syarat dilakukan ide diversi dalam perkara anak, yaitu:

1. Pelaku anak yang baru pertama kali melakukan tindak pidana;

2. Umur anak relatif masih muda;

3. Implementasi bentuk programprogram diversi yang dikenakan pada anak mendapat persetujuan pada orang tua/wali, maupun anak yang bersangkutan;

4. Kejahatan yang dilakukan dapat tindak pidana yang ringan ataupun yang berat (dalam kasus tertentu);

5. Anak telah mengaku bersalah melakukan tindak pidana/ kejahatan;

6. Masyarakat mendukung dan tidak keberatan, atas pengalihan pemeriksaan ini;

7. Jika pelaksanaan program diversi gagal, maka pelaku anak tersebut dikembalikan untuk diperiksa secara formal ${ }^{28}$.

Undang-Undang Narkotika tidak secara khusus mengatur tentang stelsel sanksi bagi anak, misalnya dalam ketentuan Pasal 111, Pasal 112 atau Pasal 114 Undang-Undang Narkotika tidak ada pernyataan tentang pengaturan anak, maka dari itu dalam

28 Made Ayu Citra Maya Sari, Loc.Cit.
Undang-Undang Narkotika terhadap anak yang menyalahgunakan narkotika juga harus mengacu pada UU SPPA sebagai ketentuan khususnya.

Pedoman pemidanaan bagi anak terdapat pada rumusan UU SPPA dalam ketentuan Pasal 71 sampai dengan Pasal 81. Ketentuan Pasal 81 ayat (2) menyatakan bahwa pidana penjara yang dapat dijatuhkan kepada anak paling lama $1 / 2$ (satu perdua) dari maksimum ancaman pidana penjara bagi orang dewasa. Mengingat bahwa pidana penjara terhadap anak hanya digunakan sebagai upaya terakhir, maka dari itu dalam sistem peradilan pidana anak wajib mengutamakan pendekatankeadilanrestoratifdanwajib diupayakan diversi, hal tersebut sesuai dengan pernyataan pada ketentuan Pasal 5 UU SPPA. Pelaksanaan diversi diatur pada ketentuan Pasal 7 ayat (2) yang menyatakan bahwa diversi dilaksanakan dalam hal tindak pidana yang dilakukan:

a. diancam dengan pidana penjara di bawah 7 (tujuh) tahun; dan

b. bukan merupakan pengulangan tindak pidana.

Seseorang yang melakukan tindak pidana narkotika, ancaman hukumannya adalah minimal tiga bulan pidana kurungan serta minimal satu tahun pidana penjara, dan maksimal pidana penjara seumur hidup atau pidana mati, dan denda paling rendah Rp1.000.000,00 (satu juta rupiah) dan denda maksimal Rp20.000.000.000,00 (dua puluh miliar rupiah). Dalam hal 
tindakpidanayang dilakukanoleh anak, hanya anak yang melakukan tindak pidana yang diatur pada ketentuan Pasal 127 ayat (1) dan ketentuan Pasal 131 Undang-Undang Narkotika yang dapat dilakukan upaya diversi oleh karena hanya ketentuan tersebutlah ancaman pidana penjaranya yang di bawah 7 (tujuh) tahun. Ketentuan Pasal 127 ayat (1) Undang-Undang Narkotika menyatakan bahwa setiap penyalah guna:

a. Narkotika Golongan I bagi diri sendiri dipidana dengan pidana penjara paling lama 4 (empat) tahun;

b. Narkotika Golongan II bagi diri sendiri dipidana dengan pidana penjara paling lama 2 (dua) tahun; dan

c. Narkotika Golongan III bagi diri sendiri dipidana dengan pidana penjara paling lama 1 (satu) tahun.

Ketentuan Pasal 131 UndangUndang Narkotika menyatakan bahwa: "Setiap orang yang dengan sengaja tidak melaporkan adanya tindak pidana sebagaimana dimaksud dalam Pasal 111, Pasal 112, Pasal 113, Pasal 114, Pasal 115, Pasal 116, Pasal 117, Pasal 118, Pasal 119, Pasal 120, Pasal 121, Pasal 122, Pasal 123, Pasal 124, Pasal 125, Pasal 126, Pasal 127 ayat (1), Pasal 128 ayat (1), dan Pasal 129 dipidana dengan pidana penjara paling lama 1 (satu) tahun atau pidana denda paling banyak Rp50.000.000,00 (lima puluh juta rupiah)".
Proses diversi dilaksanakan melalui musyawarah dengan melibatkan anak dan juga orang tua maupun walinya, korban dan atau orang tua atau walinya, pembimbing kemasyarakatan dan juga pekerja sosial profesional berdasarkan pendekatan keadilan restoratif. Dalam pelaksanaan proses diversi ini wajib diperhatikan mengenai kepentingan korban, kesejahteraandantanggungjawabanak, penghindaran anak dari stigma negatif, penghindaran anak dari pembalasan, keharmonisan masyarakat, dan juga wajib diperhatikan hal-hal lain seperti kepatutan, kesusilaan, dan ketertiban umum. Apabila dalam proses diversi tidak menghasilkan kesepakatan atau kesepakatan diversi tidak dilaksanakan maka sesuai ketentuan Pasal 13 UU Sistem Peradilan Anak maka akan dilanjutkan pada proses peradilan pidana anak.

\section{KESIMPULAN}

1. Penjatuhan pidana pada dasarnya adalah karena seseorang telah melakukan suatu kejahatan atau tindak pidana. Anak yang berhadapan dengan hukum dalam hal melakukan tindak pidana narkotika yang dijatuhi pidana bertujuan untuk memperbaiki pribadi dari anak itu sendiri, untuk membuat anak menjadi jera dalam melakukan kejahatan-kejahatan, dan untuk membuat residivis anak menjadi tidak mampu melakukan 
kejahatan lagi. Namun, pada lain sisi penjatuhan pidana terhadap anak malah akan merugikan anak tersebut di kemudian hari. Penerapan sanksi pidana anak akan menimbulkan dampak negatif berupa kerugiankerugian, yaitu anak menjadi lebih ahli tentang kejahatan, anak diberi cap jahat oleh masyarakat yang disebut stigma, masa depan anak menjadi suram, bahkan dalam kehidupan bermasyarakat, masyarakat menolak kehadiran mantan narapidana anak.

2. UU SPPA bertujuan sebagai sarana untuk mendukung mewujudkan kesejahteraan anak pelaku tindak pidana. Maka dari itu dalam UU SPPA adanya upaya diversi bagi anak dalam ketentuan Pasal 1 angka 7, diversi adalah pengalihan penyelesaian perkara Anak dari proses peradilan pidana ke proses di luar peradilan pidana. UndangUndang Narkotika belum mengatur mengenai pengaturan anak yang menyalahgunakan narkotika, maka dari itu dalam Undang-Undang Narkotika terhadap anak juga harus mengacu pada UU SPPA sebagai ketentuan khususnya. Undang-Undang Narkotika mengenai anak, hanya anak yang melakukan tindak pidana yang diatur pada ketentuan Pasal 127 ayat (1) dan ketentuan Pasal 131
Undang-Undang Narkotika yang dapat dilakukan upaya diversi oleh karena hanya ketentuan tersebutlah ancaman pidana penjaranya yang di bawah 7 (tujuh) tahun. Pidana penjara terhadap anak hanya digunakan sebagai upaya terakhir, maka dari itu jika proses diversi tidak menghasilkan kesepakatan maka sesuai ketentuan Pasal 13 UU Sistem Peradilan Anak maka akan dilanjutkan pada proses peradilan pidana anak.

\section{DAFTAR PUSTAKA}

Buku:

Adi, Koesno, 2014, Diversi Tindak Pidana Narkotika Anak, Setara Press, Malang.

Ali, Zainuddin, 2009, Metode Penelitian Hukum, Sinar Grafika, Jakarta.

Gultom, Maidin, 2008, Perlindungan

Hukum Terhadap Anak dalam

Sistem Peradilan Pidana Anak di Indonesia, Refika Aditama, Bandung.

Jamil, M. Nasir, 2013, Anak Bukan Untuk Dihukum, Sinar Grafika, Jakarta.

Lamintang, P.A.F. dan Theo Lamintang, 2012, Hukum

Penitensier, Cetakan Kedua, Sinar Grafika, Jakarta.

Lisa FR, Julianan dan Nengah Sutrisna W, 2013, Narkoba, Psikotropika, dan Gangguan Jiwa Tinjauan Kesehatan dan Hukum, Nuha Medika, Yogyakarta. 
Mahmud Marzuki, Peter, 2011, Penelitian Hukum, Kencana Prenada Media Group, Jakarta.

Marpaung, Leden, 2012, Asas-TeoriPraktik Hukum Pidana, Sinar Grafika, Jakarta.

Muhammad, Abdulkadir, 2004, Hukum dan Penelitian Hukum, PT Citra Aditya Bakti, Bandung.

O Christiansen, Karl, 1974, Some Consideration on the Possibility of a Rational Criminal Policy, Resource Material Series No.7, UNAFEI, Tokyo.

Soetodjo, Wagiati, 2006, Hukum Pidana Anak, PT.Refika Aditama, Bandung.

Wahyudi, Setya, 2011, Implementasi Ide Deversi Dalam Pembaharuan Sistem Peradilan Anak Di Indonesia, Cet. Ke 1, Genta Publishing, Yogyakarta.

\section{Artikel majalah ilmiah:}

Pangaribuan, Susi, 2012, Tinjauan

Terhadap Sistem Pemidanaan

Minimal Bagi Anak Dalam

Perkara Narkotika Dengan

Kerangka Kepentingan Terbaik Anak, Varia Peradilan, No. 325.

\section{Artikel majalah ilmiah versi online:}

Wahyu Chandra Satriana,IMade, 2013, Kebijakan Formulasi Keadilan Restoratif Dalam Sistem Peradilan Pidana Anak, Jurnal Magister Hukum Udayana, No. 3, Vol. 3, Edisi Juli 2013, http://ojs.unud.ac.id/index.php/ $\mathrm{jmhu} /$ article/view/7309, diakses tanggal 29 Desember 2016.

Ayu Citra Maya Sari, Made, 2013, Diversi Dalam Sistem Peradilan Pidana Anak Di Indonesia, Jurnal Magister Hukum Udayana, No. 1, Vol. 2, Edisi Pebruari 2013, http://ojs.unud.ac.id/index.php/ $\mathrm{jmhu} /$ article/view/4439, diakses tanggal 29 Desember 2016.

Artha, I Gede dan I Wayan Wiryawan, Pengendalian Peredaran Gelap Narkotika Oleh Narapidana Dari DalamLembagaPemasyarakatan (LAPAS), Jurnal Magister Hukum Udayana, No. 3, Vol. 4, Edisi September 2015, http:// ojs.unud.ac.id/index.php/jmhu/ article/view/18065, diakses tanggal 29 Desember 2016.

\section{Peraturan Perundang-Undangan:}

Kitab Undang-Undang Hukum Pidana (KUHP)

Undang-Undang No. 35 Tahun 2009 Tentang Narkotika Lembaran Negara Republik Indonesia Tahun 2009 Nomor 143, Tambahan Lembaran Negara Republik Indonesia Nomor 5062.

Undang-Undang Republik Indonesia Nomor 11 Tahun 2012 Tentang Sistem Peradilan Pidana Anak Lembaran Negara Republik Indonesia Tahun 2012 Nomor 153, Tambahan Lembaran Negara Republik Indonesia Nomor 5332. 